\title{
Ruy Barbosa e a queima dos arquivos: as lutas pela memória da escravidão e os discursos dos juristas*
}

Evandro Piza Duarte ${ }^{1}$ Guilherme Scotti ${ }^{2}$ Menelick de Carvalho Netto ${ }^{3}$
Recebido em: 31/08/2015. Aprovado em: 15/09/2015.

Doutor em Direito, Estado e Constituição pela Universidade de Brasília (UnB). Professor Adjunto de Direito Penal, Processo Penal e Criminologia da Universidade de Brasília (UnB). Autor de Criminologia e Racismo. Juruá, 2002. E-mail: evandropiza@ gmail.com.

2 Doutor em Direito, Estado e Constituição pela Universidade de Brasília (UnB). Professor Adjunto de Teoria e Filosofia do Direito da Universidade de Brasília (UnB). E-mail: gscotti@ unb.br.

3 Doutor em Direito pela Universidade Federal de Minas Gerais (UFMG). Professor Associado de Direito Constitucional da Universidade de Brasília (UnB). E-mail: menelickcnetto@unb.br.

\section{Ruy Barbosa and the burning of files: the struggles for the memory of slavery and the discourses of legal scholars}

\section{Resumo}

O presente artigo explora o incidente conhecido como "A Queima dos Arquivos da Escravidão por Ruy Barbosa”. Todavia, não pretende estabelecer uma verdade sobre qual seria o autor da decisão que levou à queima das matrículas dos escravos. Ao invés disso, com base no debate surgido no julgamento do Habeas Corpus $n^{\circ} 82.424 / R S$ do Supremo Tribunal Federal sobre a Imprescritibilidade do Crime de Racismo e da recente criação da Comissão da Verdade da Escravidão Negra no Brasil pela OAB (2015), intenta compreender como os discursos sobre a escravidão se inserem na retórica dos juristas sobre as demandas por reconhecimento dos negros (afrodescendentes). A importância desse debate decorre do fato de que as demandas por reconhecimento propõem, grosso modo, construções sobre fatos no presente (recurso à apresentação empírica e à interpretação sociológica) e no passado (recurso à historiografia e às interpretações sobre a constituição das relações raciais). O "episódio" sinaliza primeiro um problema estrutural das demandas dos negros: o modo como a historiografia oficial sobre a construção da nacionalidade inseriu sua presença e suas lutas por reconhecimento. Sinaliza também as razões pelas quais a ideia de "apagamento da memória" constitui-se como elemento decisivo dos padrões de desrespeito para com esse grupo.

Palavras-chave: Racismo. Constituição. Escravidão. Ruy Barbosa. Queima de arquivos. História. Memória. Direto constitucional.

\section{Abstract}

This article explores the incident known as "The Burning of the Slavery Archives by Ruy Barbosa." However, establishing the truth about who is the author of the decision which led to the burning of slaves enrollment documents is not intended. Instead, from the debate that emerged in the Habeas Corpus decision $n^{\circ} 82.424 /$ RS of the brazilian Supreme Court about the imprescriptibility of the crime of racism and the recent creation of the Truth Commission for the Black Slavery in Brazil by the Brazilian Bar Association (2015), it tries to understand how the discourses about slavery fall into the rhetoric of lawyers on the demands for recognition of black people (of African descent). The importance of this debate stems from the fact that demands for recognition propose, roughly, the reconstruction of present (use of empirical presentation and sociological interpretation) and past (use of historiography and interpretations of the constitution of race relations ) facts. Firstly, the "episode" signals a structural problem of the demands of black people: the ways official historiography on the construction of nationality inserted their presence and their struggles for recognition. And, secondly, the reasons why the notion of "memory erasure" was established as a key element of the patterns of disrespect toward this group.

Keywords: Racism. Constitution. Slavery. Ruy Barbosa. File burning. History. Memory. Constitutional right. 


\section{Introdução}

Este artigo explora o incidente conhecido como "A Queima dos Arquivos da Escravidão por Ruy Barbosa". Todavia, não pretende estabelecer uma verdade sobre qual seria o autor da decisão que levou à queima das matrículas dos escravos. Ao invés disso, com base no debate surgido no julgamento do Habeas Corpus $\mathrm{n}^{\circ}$ 82.424/RS do Supremo Tribunal Federal sobre a imprescritibilidade do crime de racismo, intenta compreender como esse "fato" se insere na retórica dos juristas sobre as demandas por reconhecimento dos negros (afrodescendentes).

A importância desse debate decorre do fato de que as demandas por reconhecimento propõem, grosso modo, construções sobre fatos no presente (recurso à apresentação empírica e à interpretação sociológica) e no passado (recurso à historiografia e às interpretações sobre a constituição das relações raciais). O "episódio" sinaliza primeiramente um problema estrutural das demandas dos negros, o modo como a historiografia oficial sobre a construção da nacionalidade inseriu sua presença e suas lutas por reconhecimento. Sinaliza também as razões pelas quais a ideia de "apagamento da memória" constitui-se como elemento decisivo dos padrões de desrespeito para com esse grupo 4 .

Nesse contexto, sugere-se que a retórica da "impossibilidade da memória" deve ser superada por interpretação constitucional que reconhece o pluralismo da Constituição como proposta de releitura dos direitos fundamentais, admitindo passado de uma sociedade moldada a partir da escravidão, do colonialismo e do racismo, e um presente de exclusões deles decorrentes. Portanto, em vez de um confinamento hermenêutico da Ordem Constitucional da Cultura e do esquecimento dos dispositivos que tratam da presença dos negros em nossa história, impõe-se ao intérprete a releitura dos direitos fundamentais com base nesse ponto estrutural da nossa trajetória constitucional.

De fato, a preocupação com a memória e seus usos sociais fundamenta a criação da Comissão da Verdade da Escravidão Negra no Brasil pela Ordem dos Advogados do Brasil (2015) que representa oportunidade para reflexão sobre as violações de direitos fundamentais reforçados por narrativas históricas hegemônicas.

\section{Como lembramos: tradição negreira na histó- ria brasileira}

Há algumas décadas, um livro compunha a estante de livros de muitas casas: Crestomatia Cívica: Uma só Pátria, Uma só Bandeira - O Brasil Novo e Seus Problemas, por meio de excertos de escritores da atualidade, apresentado a consideração e carinho da juventude das escolas", editado, em Porto Alegre, pela Livraria do Globo, em 1938. Em texto intitulado "Os Escravos no Brasil", lia-se o seguinte:

Não é nosso intento fazer a apologia da escravidão, cujos horrores principalmente macularam o homem branco e sobre ele recaíram. Mas a escravidão no Brasil foi para os negros a reabilitação deles próprios e trouxe para a descendência deles uma pátria, a paz e a liberdade e outros bens que pais e filhos jamais lograriam gozar ou sequer entrever no seio bárbaro da África. ${ }^{5}$.

Esse pequeno trecho resume a primeira parte do problema abordado neste texto: o modo como a historiografia dominante integrou simbolicamente a presença dos "negros" à sociedade brasileira, durante e após a escravidão. Quanto a isso, deveria ser suficiente a advertência de Clóvis Moura para quem:

os estudos sobre o negro brasileiro, nos seus diversos aspectos, têm sido mediados por preconceitos acadêmicos, de um lado, comprometidos com uma pretensa imparcialidade científica, e, de outro, por uma ideologia racista racionalizada, que representa os resíduos da superestrutura escravista, e, ao mesmo tempo, sua continuação [...]"6.

De fato, daquele trecho se infere elementos de uma ideologia em voga em períodos nacionalistas, na Ditadura Vargas e na Ditadura Militar de 1964ㄱ, e que subjazem (ou convivem amigavelmente) com o "mito da democracia racial"': a) a escravidão era um mal africano, logo foi a América que trouxe a liberdade aos negros; b) eles foram emancipados de suas sociedades bárbaras e de sua própria natureza bárbara com a escravidão no Brasil; c) a incorporação à sociedade brasileira (apesar de

TABORDA, Radagasio. Crestomatia cívica: uma só pátria, uma só bandeira! Porto Alegre: Livraria do Globo, 1938. p. 97.

6 MOURA, Clóvis. Sociologia do negro brasileiro. São Paulo: Ática, 1988. p. 17.

7 CHAUÍ, Marilena de Sousa. Conformismo e resistência: aspectos da cultura popular no Brasil. São Paulo: Brasiliense, 1986; CHAUÍ, Marilena de Sousa. Brasil: mito fundador e sociedade autoritária. São Paulo: Fundação Perseu Abramo, 2000.

8 ORTIZ, Renato. Cultura brasileira e identidade nacional. São Paulo: Brasiliense, 1994. 
forçada) foi o auge de uma expectativa de "destino" da raça negra; d) ela lhes garantiu sua incorporação à pátria ou à nação; e) de fato, quem efetivamente sofreu com a escravidão foram os brasileiros (brancos em geral), obrigados a conviverem com a marca do atraso em suas relações econômicas e não conseguiram desenvolver todo o potencial; f) enfim, a escravidão foi um mal para o Brasil e para os próprios senhores de escravos, mas não foi um mal tão grande para os "bárbaros negros".

A fonte mais remota dessa tradição negreira de representação dos negros na história "nacional" encontra-se no que Henrique Dussel denunciou como o "Mito da Modernidade". Se, por um lado, a Modernidade em seu conteúdo positivo seria a "emancipação racional" da humanidade, por outro, em seu conteúdo secundário e negativo mítico, ela foi a justificação de uma práxis irracional de violência que atribui uma "culpa" ao outro que não se submete ao domínio europeu ${ }^{9}{ }^{10}$

A ideia de "negro" e a práxis social dominante que busca circunscrevê-la está marcada por essa violência constitutiva. Assim, por exemplo, para os Letrados que justificaram a escravidão antes do século XIX: a) os negros não foram propriamente "vítimas", pois tinham be-

9 DUSSEL, Enrique D. 1492, o encobrimento do outro: a origem do mito da modernidade. Petrópolis: Vozes, 1993. p. 185-186.

10 Dessa forma: "a) a civilização moderna se autocompreende como mais desenvolvida, superior (o que significará sustentar, sem a consciência, uma posição ideologicamente eurocêntrica); b) a superioridade obriga, como exigência moral, a desenvolver os mais primitivos, rudes, bárbaros; c) o caminho do referido processo educativo de desenvolvimento será o seguido pela Europa (é, de fato, um desenvolvimento unilinear e à europeia, o que determina, novamente sem consciência alguma, a 'falácia desenvolvimentista'); d) como o bárbaro se opõe ao processo civilizador, a práxis moderna deve exercer, em último caso, a violência, se for necessário, para destruir os obstáculos de tal modernização (a guerra justa colonial); e) esta dominação produz vítimas (de muitas variadas maneiras), violência que é interpretada como um ato inevitável e com o sentido quase ritual de sacrifício; o herói civilizador investe suas próprias vítimas do caráter de serem holocaustos de um sacrifício salvador (do colonizado, escravo africano, da mulher, da destruição ecológica da terra, etc.); f) para o moderno, o bárbaro tem uma "culpa" (o fato de se opor ao processo civilizador), que permite que a "modernidade" se apresente não só como inocente mas também como "emancipadora" dessa "culpa" de suas próprias vítimas. g) por último, e pelo caráter "civilizatório" da "modernidade", são interpretados como inevitáveis os sofrimentos ou sacrifícios (os custos) da "modernização" dos outros povos "atrasados" (imaturos), das outras raças escravizáveis, do outro sexo por ser fraco etc." DUSSEL, Enrique D. 1492, o encobrimento do outro: a origem do mito da modernidade. Petrópolis: Vozes, 1993. p. 185-186. nefícios secundários com sua escravidão (os filhos eleitos de Maria, segundo Padre Antônio Vieira, sofredores na terra, mas purificados para o céu); b) os negros seriam as vítimas de si mesmos, de suas incapacidades e, portanto, a ideia de guerra justa não necessitava se apoiar numa reação concreta defensiva, bastando a condição de ser negro para justificá-la ${ }^{11}$; desse modo, a existência de uma "culpa originária" e a necessidade de "emancipação de seu ser pela violência" compuseram o cerne das representações negreiras sobre os "negros". Não por acaso, Frantz Fanon $^{12}$, em os "Condenados da Terra", ao descrever as dimensões subjetivas da violência empreendida pelos europeus no colonialismo na África, escolheu apropriadamente o termo "Les Dammés de La Terre", termo que significa condenação, maldição e expiação (purgação) da culpa, e, ao mesmo tempo, identifica aqueles que foram objeto de uma decisão judicial e estão cumprindo pena, unindo conceito supostamente laico e outro religioso, e, nessa união, demonstrando como, para os negros, se construiu uma sobreposição entre responsabilidade do sujeito (responsável por ser negro) e responsabilidade por uma "ação" praticada (responsabilidade por ter praticado um ato). Desse modo, eram bárbaros, não porque empreendessem "guerra justa", mas por estarem excluídos do $\log o s^{13}$.

Entretanto, para além desse contexto mais geral, a história da nação brasileira, e do lugar do negro nessa história, estão associados à formação do que Marilena Chauí chamou de "Mito Fundador", ou seja, narrativa de feitos lendários da comunidade, referida às suas origens, e que representa solução imaginária de conflitos, não resolvidos no plano real. Tal mito, compartilhado por amplos setores da sociedade brasileira, estaria composto de três elementos (a visão do paraíso, a história teológica providencial e a teoria da soberania fundada na vontade divina) que "aparecem, nos séculos XVl e XVll, sob a forma das três operações divinas que, no mito fundador, respondem pelo Brasil: a obra de Deus, isto é, a Natureza,

VAINFAS, Ronaldo. Ideologia e escravidão: os letrados e a sociedade escravista no Brasil colonial. Petrópolis: Vozes, 1986; BARROS, José D’Assunção. A construção social da cor: diferença e desigualdade na formação da sociedade brasileira. Petrópolis: Vozes, 2009; BOSI, Alfredo. Dialética da colonização. São Paulo: Companhia das Letras, 1992.

12 FANON, Frantz. Os condenados da terra. Trad. de José Laurênio de Melo. Rio de Janeiro: Civilização Brasileira, 1979.

13 ZEA, Leopoldo. Discurso desde a marginalização e a barbárie; seguido de, A filosofia latino-americana como filosofia pura e simplesmente. Rio de Janeiro: Garamond, 2005. 
a palavra de Deus, isto é, a história, e a vontade de Deus, isto é, o Estado." ${ }^{14}$

O primeiro componente, a visão do paraíso, não excluía a justificação da escravidão que era mediada por uma referência à teoria da obediência em que a liberdade conduzia ao respeito da ordem. Esse mito fundador propõe a concepção de que os naturais, os dispostos na natureza, não possuem direitos. Eles integram uma história que se realiza pela vontade dos governantes que encarna uma força transcendente, enquanto os governados, ao contrário, estão despidos de vontade. Não há espaço para a ação política, pois, nesse mito, ela é entendida apenas como a distribuição de favores, das dádivas dos governantes. Tampouco, a partir dele se pode pensar numa cidadania universalizada, pois: há aqueles que estão na condição de "naturais", sem direitos; há os homens despidos de seus direitos por Deus, mas que podem receber as dádivas dos governantes; estes que, por seu turno, as receberam de Deus e encarnam a história, mas devem respeitar a propriedade absoluta e partilhar de seu domínio com os escolhidos, mediante a troca de favores ${ }^{15}$.

Desse modo, as demandas por liberdade e por igualdade dos negros e indígenas não encontram lugar nessa história contada pelo Mito Fundador, pois eles não participam do mundo na qualidade de sujeitos. Ao invés disso, suas demandas são percebidas como desvios na natureza ou como traços de sua condição natural de viventes. Esse lugar (a "natureza”) é outra constante nas formas de tratar o "comportamento" dos negros e indígenas, tendo sido extensamente difundido em diferentes narrativas (antropológicas: relativistas, evolucionistas, biologicistas; culturalistas sociológicas: marxistas e funcionalistas; e historiográficas).

Entretanto, somente no século XIX, o Mito Fundador do Brasil foi desenvolvido como tradição historiográfica. Nesse caso, o modelo que explica a formação da ideia de nação brasileira nasceu de uma combinação contraditória de duas interpretações distintas que, aparentemente, se excluem: uma influenciada pelo "cientificismo naturalista evolucionista e positivista" e outra pela "escola histórica alemã”, na tradição historiográfica do Instituto Histórico e Geográfico Brasileiro ${ }^{16}$. Constituíram-se em

14 CHAUÍ, Marilena de Sousa. Brasil: mito fundador e sociedade autoritária. São Paulo: Fundação Perseu Abramo, 2000. p. 58.

15 CHAUÍ, Marilena de Sousa. Brasil: mito fundador e sociedade autoritária. São Paulo: Fundação Perseu Abramo, 2000. p. 60.

16 CHAUÍ, Marilena de Sousa. Brasil: mito fundador e so- duas tradições de pensamento, capazes de construir um lugar para os naturalizados como desiguais, negando-lhes a condição de sujeitos. De igual modo, são as supostas fontes "autorizadas" às quais se recorre para construir retrato das relações raciais no país.

A ideia política de uma história oficial para o Brasil e para os diferentes grupos "raciais" tem sua origem em 1838, quando o referido instituto foi criado com o intuito de oferecer ao "país independente um passado glorioso e um futuro promissor, com o que legitimaria o poder do Imperador”. Em um de seus concursos, o naturalista alemão Von Martius apresentou a monografia vencedora sobre "Como se deve escrever a história do Brasil"17 e definiu qual seria o paradigma de construção de nossa história: "cabia ao historiador brasileiro redigir uma história que incorporasse as três raças, dando predominância ao português, conquistador e senhor que assegurou o território e imprimiu suas marcas morais ao Brasil."1819 A proposta oficial de uma história do Brasil como integração subordinada nasce, portanto, no Império, num regime escravagista que foi o último a abolir a escravidão. Todavia, foi com o surgimento da obra de Gilberto Freyre $^{20}$, Casa Grande e Senzala, na década de 1930, por fixar a falsa ideia da existência de dois modelos explicativos ideais quanto à questão racial (um baseado no conflito, o norte-americano, e outro na integração, o brasileiro) que ela adquiriu ares definitivos de cientificidade ${ }^{21}$. Como demonstrou Kabengele Munanga:

ciedade autoritária. São Paulo: Fundação Perseu Abramo, 2000. p. 49.

17 VON MARTIUS, Carlos Frederico. Como se deve escrever a historia do Brasil. Jornal do Instituto Histórico e Geográfico Brasileiro, Rio de Janeiro, n. 24, p. 401-402, jan. 1845.

18 CHAUÍ, Marilena de Sousa. Brasil: mito fundador e sociedade autoritária. São Paulo: Fundação Perseu Abramo, 2000. p. 49-50.

19 Na obra de Afonso Celso é apresentado outro dos elementos desse paradigma, os heróis de fato são heróis de uma guerra travada pelos jesuítas e suas missões, os bandeirantes e suas entradas e bandeiras etc., correspondendo ao princípio da nacionalidade, segundo Marilena Chauí, "que define a nação não somente por seu território presente, mas por sua capacidade de expansão, conquista e unificação de territórios novos." CHAUÍ, Marilena de Sousa. Brasil: mito fundador e sociedade autoritária. São Paulo: Fundação Perseu Abramo, 2000. p. 54.

20 FREYRE, Gilberto. Nordeste: aspectos da influência da cana sobre a vida e a paisagem do nordeste do Brasil. Rio de Janeiro: Record, 1989.

21 IANNI, Octávio. Escravidão e racismo. São Paulo: Hucitec, 1988. p. 126-139; ARAÚJO, Ricardo Benzaquen de. Guerra e paz: casa-grande e senzala e a obra de Gilberto Freyre nos anos 30. Rio de Janeiro: 34, 1994. 
o mito de democracia racial, baseado na dupla mestiçagem biológica e cultural entre as três raças originárias, tem uma penetração muito profunda na sociedade brasileira: exalta a ideia de convivência harmoniosa entre os indivíduos de todas as camadas sociais e grupos étnicos, permitindo às elites dominantes dissimular as desigualdades e impedindo os membros das comunidades não brancas de terem consciência dos sutis mecanismos de exclusão da qual são vítimas na sociedade. Ou seja, encobre os conflitos raciais, possibilitando a todos se reconhecerem como brasileiros e afastando das comunidades subalternas a tomada de consciência de suas características culturais que teriam contribuído para a construção e expressão de uma identidade própria. Essas características são "expropriadas", "dominadas" e "convertidas" em símbolos nacionais pelas elites dirigentes ${ }^{22}$.

Instaura-se uma ideia de "pluralismo" que pressupõe e aceita a aniquilação das diferenças e, ao mesmo tempo, encerra a diferença no plano social (natural e privado), afastando-a do plano político e jurídico. Novamente, negros e indígenas são remetidos ao plano da "natureza", alheio ao espaço da política. Essa ideologia representa, não uma ruptura, mas uma dupla continuação: com a historiografia criada para justificar o poder do Imperador e a manutenção de uma sociedade escravista e com as ideologias racistas formuladas pelo cientificismo, em especial as teses sobre o branqueamento da população brasileira ${ }^{23}$.

Por sua vez, a convivência, ao longo da história republicana, entre a ideologia da "democracia racial", com sua máscara de uma ideologia aparentemente integradora, e o autoritarismo político, uma ideologia que privilegia a desmobilização política e nega o pluralismo politico, indica o caráter antidemocrático, antiliberal, desmobilizador e de modernização conservadora do mito da integração racial. Como sintetizou Octávio Ianni ${ }^{24}$, enquanto a ideologia da democracia racial serviu para "explicar a sociedade", o autoritarismo político serviu para "explicar o Estado". Isso porque, como demonstrou Clóvis Moura, a defesa das oligarquias que iria constituir e organizar o Estado "modernizado" (Oliveira Vianna) continuou a

22 MUNANGA, Kabengele. Rediscutindo a mestiçagem no Brasil. Belo Horizonte: Autentica, 2004. p. 89.

23 CHIAVENATO, Júlio J. O negro no Brasil: da senzala à Guerra do Paraguai. São Paulo: Brasiliense, 1986. p. 167189; MOURA, Clóvis. Dialética radical do negro no Brasil. São Paulo: Anita, 1994. p. 79-86; SKIDMORE, Thomas. Preto no branco. Rio de Janeiro: Paz e Terra, 1976.

24 IANNI, Octávio. A ideia de Brasil moderno. São Paulo: Brasiliense, 1994. p. 85. obra dos "senhores patriarcais" que haviam constituído a sociedade (Gilberto Freyre):

as oligarquias de Oliveira Vianna têm muita semelhança com os senhores de engenho idealizados por Gilberto Freyre, pois são as formas diversificadas de um mesmo fenômeno. Ambos criaram e mantiveram os suportes justificatórios de uma sociedade de privilegiados, no Império e na República. Entre os dois pensamentos há uma constante, a inferiorização social e racial do negro, segmentos mestiços e índios e a exaltação cultural e racial dos dominadores brancos ${ }^{25}$.

De modo mais direto, há continuidade entre a "constatação" freyriana do suposto "masoquismo do negro" ${ }^{26}$ e a "necessidade científica" de Oliveira Vianna ${ }^{27}$ de que tenhamos Estado forte para plasmar com sua força a sociedade ${ }^{28}$. Em ambos, os conflitos entre grupos sociais são transformados em processos anônimos de forças sociais, culturais, raciais etc., e, ao fim, terminam por naturalizar a violência empreendida por determinados grupos como redentora, pois são capazes de produzir "criativamente" as marcas de uma Nação. Nada resta da perspectiva dos vencidos e suas lutas cotidianas, sociais, culturais etc. De fato, a expressão "democracia racial", cegamente utilizada, esconde absurdo intrínseco: num país com constantes lapsos de democracia, seja em longos períodos de autoritarismo politico ou em práticas autoritárias cotidianas ainda presentes, a única democracia comemorada publicamente é a racial, mesmo que essa democracia nada diga a propósito dos direitos dos negros.

Enfim, o suposto discurso autorizado para explicar o Brasil e suas relações raciais é o encontro da exclusão promovida pelo escravismo (a historiografia do Império) e para promover a não cidadania dos negros no período de abolição e na construção da República (o

25 MOURA, Clóvis. Sociologia do negro brasileiro. São Paulo: Ática, 1988. p. 24.

26 FREYRE, Gilberto. Nordeste: aspectos da influência da cana sobre a vida e a paisagem do nordeste do Brasil. Rio de Janeiro: Record, 1989.

27 VIANNA, Francisco José de Oliveira. Evolução do povo brasileiro. Rio de Janeiro: J. Olympio, 1956; VIANNA, Francisco José de Oliveira. Instituições políticas brasileiras. Belo Horizonte: Atalaia, 1987. v. 1; VIANNA, Francisco José de Oliveira. Instituições políticas brasileiras. Belo Horizonte: Atalaia, 1987. v. 2.

28 CARVAlHO, José Murilo de. A utopia de Oliveira Vianna. Revista Estudos Históricos, Rio de Janeiro, v. 4, n. 7, p. 81-89, 1991. Disponível em: <http://virtualbib.fgv.br/ojs/ index.php/reh/article/viewArticle/2310>. Acesso em: 20 out. 2015. 
cientificismo racista) ${ }^{29}$. O processo de individualização de uma memória da presença negra na formação do Império oculta a presença ativa do negro, em nome de sua incapacidade natural-histórica e da falsa representação da escravidão benigna criada para justificar a perpetuação da escravidão no Brasil e para manter as hierarquias sociorraciais, atribuindo à "raça negra" os males da escravidão. Essa problemática do negro como integrante da sociedade brasileira será revisitada constantemente quer pela tradição cientificista quer pelos herdeiros da tradição romântica e ora defender-se-á a miscigenação como modo de extermínio gradual da presença negra (Oliveira Vianna), ora como forma de integração subordinada (Gilberto Freyre).

Em síntese, o lugar do negro na história brasileira insere-se numa "estrutura de verdade" ${ }^{30}$ que propõe uma forma de narrar ${ }^{31}$ e de impedir outras narrativas. Para essa tradição negreira, não haverá espaço para pensar o negro como sujeito de sua história, porque ele está situado na natureza, no plano dos fenômenos, mas não das subjetividades. As lutas pela liberdade dos negros não poderão tampouco ser retratadas em sua dimensão política cotidiana e institucional para a constituição de direitos.

A demarcação desse espaço de negação do negro na sociedade brasileira somente é possível com uma ação contínua sobre as memórias coletivas, cotidianas e populares. Mas como impedir a memória? Como demonstrou Paolo Rossi, a evocação e o apagamento não podem ser tratados como fenômenos da natureza. A memória social não se constrói apenas com base nos comportamentos psicofisiológicos ${ }^{32}$. A negação do negro dependeu da institucionalização, da memória (da tradição negreira) nos aparelhos ideológicos de Estado ${ }^{33}$, nos museus, nas universidades, nos institutos de pesquisa, no sistema educacional e nos livros da estante de nossas casas. Ela implica ação contínua e cotidiana para produzir o apagamento da

29 DUARTE, Evandro C. Piza. Criminologia e racismo: introdução à criminologia brasileira. Curitiba: Juruá, 2002.

30 ROSSI, Paolo. O passado, a memória e o esquecimento. São Paulo: Unesp, 2010. p. 21.

31 AGUIAR, Thaís. A história como recurso da mimese política brasileira. Sociedade e Cultura, Goiania, v. 10, n. 2, p. 227-239, 2007. Disponível em: <http://revistas.ufg.br/ index.php/fchf/article/viewArticle/3143>. Acesso em: 20 out. 2015.

32 ROSSI, Paolo. O passado, a memória e o esquecimento. São Paulo: Unesp, 2010. p. 31-38.

33 ALTHUSSER, Louis. Aparelhos ideológicos de estado: nota sobre os aparelhos ideológicos de estado. Rio de Janeiro: Graal, 1985. memória. Paradoxalmente, essa negação também criou seus mitos sobre a possibilidade de uma memória dos negros no Brasil ou do porque os negros não podem ter mais uma memória. Talvez, o principal seja a "Queima dos Arquivos da Escravidão" que explicaria a impossibilidade de uma memória porque um "governante" teria determinado a queima dos arquivos da história da escravidão.

\section{Como apagamos e evocamos o passado: as contradições da memória e do esquecimen- to dos Juristas}

Enfim, chega-se ao segundo ponto deste texto: de que modo a tradição negreira se articula com os argumentos jurídicos e como produz como efeito principal a desconstrução dos direitos para os negros. Nesse ponto, convém revisitar esse "Mito do Apagamento da Memória" com base nos argumentos de Juristas.

Embora o STF tenha na ADPF 186 relacionado o tema das ações afirmativas para negros à história brasileira $^{34}$, por meio no Habeas Corpus $\mathrm{n}^{\circ}$ 82.424/RS ${ }^{35}$ que essa questão surgiu. Depois de 50 anos de leis antirracistas propostas pelos movimentos sociais negros ${ }^{36}$, o primeiro caso a suscitar uma manifestação da Corte sobre a abrangência do dispositivo da Constituição de 1988 que determinava a imprescritibilidade do crime de racismo tinha por vítima os judeus. Nesse julgamento, denegou-se o habeas corpus contra acórdão do STJ que havia confirmado a condenação de um escritor e editor de publicações antissemitas. $\mathrm{Na}$ ocasião, os ministros debateram a abrangência do direito à liberdade de expressão para saber se ela compreendia o direito de editar livros antissemitas e o significado do termo "crime de racismo" e, se os judeus constituiriam uma raça, estando, portanto, protegidos pela norma que determinava, desde 1988, a exceção constitucional ao direito de prescrição ${ }^{37}$. Nesse contexto,

34 DUARTE, Evandro C. Piza; SCOTTI, Guilherme. História e memória nacional no discurso jurídico: o julgamento da ADPF 186. Universitas Jus, Brasília, v. 24, n. 3, p. 33-45, 2013. doi: 10.5102/unijus.v24i3.2611.

35 BRASIL. Supremo Tribunal Federal. Crime de Racismo e Antissemitismo: um julgamento histórico no STF, habeas corpus n. ${ }^{\circ}$ 82.424/RS. Brasília: STF, 2004.

36 SILVA JÚNIOR, Paulo Melgaço. Mercedes Baptista: a criação da identidade negra na dança. 2007. Disponível em: $<$ http://ambiente.educacao.ba.gov.br/conteudos/download/167.pdf > . Acesso em: 20 out. 2015.

37 Para uma crítica aos fundamentos axiológicos da decisão: CARVALHO NETTO, Menelick; SCOTTI, Guilherme. Os direitos fundamentais e a (in)certeza do direito: a produtivi- 
a ideia de imprescritibilidade foi central, pois remetia inexoravelmente à temporalidade. História, Memória e Esquecimento passam a ser tematizados ${ }^{38}$. A decisão trouxe à tona também algumas das concepções que compõem o senso comum dos membros do Poder Judiciário sobre a presença dos negros na sociedade brasileira.

O Ministro Marco Aurélio acompanhou o raciocínio do Ministro Relator e do Ministro Ayres Britto, concedendo o habeas corpus, contra a posição da maioria, com base em interpretação fundamentada na história brasileira. O seu foco central consistiu na preservação da liberdade de expressão em função, sobretudo, de sua dimensão pública, essencial ao regime democrático. Passível, portanto, de limitações tão somente em hipótese excepcionalíssima, não justificável no caso concreto, pois a conduta no aspecto formal não seria uma incitação ao antissemitismo e, ademais, ela não encontraria no (A) substrato histórico da sociedade brasileira, segundo sua opinião, com sua “tolerância” para como judeu, solo fértil para provocar o risco de desencadeamento de comportamentos discriminatórios. No mesmo sentido, num dos trechos de citações sobre o valor da liberdade de expressão, refere-se ao polêmico caso da "Queima dos arquivos da escravidão por Ruy Barbosa”, esboçando a tese de que (B), a ignorância sobre o passado, constitui um dos elementos determinantes da cultura brasileira e de que ela não foi natural, mas induzida pelo cerceamento da liberdade de expressão:

diante dos horrores da escravidão negra no Brasil, Rui Barbosa, à época Vice-Chefe do Governo Provisório e Ministro da Fazenda, determi-

dade das tensões principiológicas e a superação do sistema de regras. Belo Horizonte: Fórum, 2011.

38 Na síntese do Ministro Maurício Corrêa as questões debatidas eram: "não sendo os judeus uma raça, mas sim um povo, revela-se impossível o cometimento de crime de racismo contra eles, não passando o caso de simples discriminação étnica ou religiosa. Essa a tese do habeas corpus levado a julgamento que inspirou várias dúvidas e o confronto de diversas correntes de pensamento. Qual o conceito de raça humana? Existe subdivisão da raça humana? O que é racismo do ponto de vista jurídico-constitucional? Os judeus são uma raça? O povo judeu pode ser vítima de racismo? Quais os limites da liberdade de expressão do pensamento?" Ou ainda: "o preceito constitucional de imprescritibilidade do crime de racismo destina-se apenas à discriminação em relação aos negros?” Ao final, a Corte denegou o Habeas e reconheceu a imprescritibilidade da ação praticada contra os judeus. BRASIL. Supremo Tribunal Federal. Crime de Racismo e Antissemitismo: um julgamento histórico no STF, habeas corpus n. ${ }^{\circ} 82.424 / \mathrm{RS}$. Brasília: STF, 2004. p. 10. nou, por meio do Decreto de 14 de dezembro de 1890, que se destruíssem todos os documentos referentes à escravidão/Intentava com esse gesto apagar, da história brasileira, o instituto como se isso tivesse o condão de fazer desaparecer da memória nacional a carga de sofrimento suportada pelo povo africano e pelos afrodescendentes - e evitar possíveis pedidos de indenização por parte dos senhores de engenho.

O ilustre baiano não se apercebeu que determinação em tal sentido, além de imprópria a alcançar o fim desejado - apagar a mancha da escravidão feita a sangue no Brasil —, subtrairia às gerações futuras a possibilidade de estudar a fundo a memória do País, o que as impediria, por conseguinte, de formar um consciente coletivo baseado na consideração das mais diversas fontes e de emergir do legado transmitido - a ignorância ${ }^{39}$.

Nesse sentido, a trajetória do negro em nosso país estaria (C) a justificar historicamente a aplicação da norma da imprescritibilidade:

nesses termos, seria mais facilmente defensável a ideia de restringir a liberdade de expressão se a questão deste habeas resvalasse para os problemas cruciais enfrentados no Brasil, como, por exemplo, o tema da integração do negro, do índio ou do nordestino na sociedade. [...] O Brasil possui toda uma carga histórica de escravização dos negros e dos índios, bem como infelizes episódios nos quais se cultivara, especialmente por grupos discriminatórios da região sul, um ódio aos nordestinos, o que chegou até mesmo a dar ensejo a uma ridícula e absurda proposta separatista ${ }^{40}$.

Logo, segundo o Ministro, seria necessário que a solução passasse: (D) "por um exame da realidade social concreta, sob pena de incidirmos no equívoco de efetuar o julgamento a partir de pressupostos culturais europeus, a partir de acontecimentos de há muito suplantados e que não nos pertencem, e, com isso, construirmos uma limitação direta à liberdade de expressão do nosso povo baseada em circunstâncias históricas alheias à nossa realidade." ${ }^{11}$. Por fim, o Ministro (E) apresenta exemplos de livros racistas que são editados no país sem nenhuma repulsa. Entre eles o de Nina Rodrigues, "Os africanos no Brasil", "no qual defende que a razão do subdesenvolvi-

39 BRASIL. Supremo Tribunal Federal. Crime de Racismo e Antissemitismo: um julgamento histórico no STF, habeas corpus n. ${ }^{\circ}$ 82.424/RS. Brasília: STF, 2004. p. 170.

40 BRASIL. Supremo Tribunal Federal. Crime de Racismo e Antissemitismo: um julgamento histórico no STF, habeas corpus n. ${ }^{\circ}$ 82.424/RS. Brasília: STF, 2004. p.181.

41 BRASIL. Supremo Tribunal Federal. Crime de Racismo e Antissemitismo: um julgamento histórico no STF, habeas corpus n. ${ }^{\circ}$ 82.424/RS. Brasília: STF, 2004. p. 181. 
mento brasileiro foi a mistura do português com a raça negra" e do qual o Ministro extrai diversas passagens sobre a inferioridade da raça negra, e, o de José Bonifácio de Andrada e Silva, "Projetos para o Brasil", no qual há diversas alusões racistas aos indígenas que são acusados de serem "povos vagabundos, envolvidos em guerras contínuas e em roubos, não tendo freios religiosos ou civis". Aduz o Ministro, ainda, a Gilberto Freyre que teria sido "duramente censurado" porque pregava que "a miscigenação havia tornado o povo brasileiro sem segundo exemplo no mundo, e, em vez de isso revelar fraqueza, demonstrava a força do nosso povo" ${ }^{\prime 2}$.

Inicialmente, muito embora não interesse o debate mais estrito sobre a interpretação constitucional da aplicação da norma ao caso, convém demarcar o dissenso em relação à posição defendida quanto aos judeus pela minoria da $\operatorname{Corte}^{43}$. $\mathrm{O}$ argumento de que a discriminação contra judeus estaria ausente na história brasileira esbarra num longa historiografia que demonstra os processos de racialização dos judeus ${ }^{44}$. Apesar da reconstrução feita pela Corte do conceito de raça para a inclusão dos judeus, efetivamente os judeus passaram por um processo social de racionalização que extrapola a ideia de discriminação religiosa, apresentando, efetivamente, práticas de redução ao biológico ${ }^{45}$. Por fim, como apontou a posição majoritária, num marco de internacionalização da universalização dos Direitos Humanos ${ }^{46}$, e complete-se, de mundialização dos meios de comunicação, não se pode tolerar áreas de livre discriminação.

42 BRASIL. Supremo Tribunal Federal. Crime de Racismo e Antissemitismo: um julgamento histórico no STF, habeas corpus n. ${ }^{\circ}$ 82.424/RS. Brasília: STF, 2004. p. 184.

43 DUARTE, Evandro C. Piza. Do medo da diferença à liberdade com igualdade: as ações afirmativas para negros no ensino superior e os procedimentos de identificação de seus beneficiários. 2011. Tese (Doutorado) - Curso de Pós-Graduação em Direito, Universidade de Brasília, Brasília, 2011.

44 BOXER, Charles Ralph. Relações raciais no império colonial português 1415-1825. Porto: Afrontamento, 1977.

45 RIGG, Bryan Mark. Os soldados judeus de Hitler: a história que não foi contada das leis raciais nazistas e de homens de ascendência judia nas forças armadas alemãs. Trad. Marcos Santarrita. Rio de Janeiro: Imago, 2003; ARENDT, Hannah. Origens do totalitarismo: antissemitismo, imperialismo, totalitarismo. Trad. Roberto Luis Raposo. São Paulo: Companhia das Letras, 1989; AGAMBEN, Giorgio. Homo Sacer: o poder soberano e a vida nua. Belo Horizonte: UFMG, 2002. v. 1.

46 LAFER, Celso. A internacionalização dos direitos humanos: constituição, racismo e relações internacionais. Barueri: Manole, 2005.
Não obstante, a posição do Ministro apontava para tema central para o constitucionalismo brasileiro: a possibilidade de dar dimensão jurídica ao fato de que somos um país construído a partir do colonialismo e da escravidão. Como enfrentar as demandas sociais que apelam para a releitura do passado na compreensão do presente e que pretendem negar a naturalização da violação de direitos dos negros e indígenas?

E o que é esse passado que se faz presente? Na síntese de Luis Felipe de Alencastro:

na realidade, nenhum país americano praticou a escravidão em tão larga escala como o Brasil. Do total de cerca de 11 milhões de africanos deportados e chegados vivos nas Américas, 44\% (perto de 5 milhões) vieram para o território brasileiro num período de três séculos (15501856). O outro grande país escravista do continente, os Estados Unidos, praticou o tráfico negreiro por pouco mais de um século (entre 1675 e 1808) e recebeu uma proporção muito menor -, perto de 560.000 africanos -, ou seja, 5,5\% do total do tráfico transatlântico. No final das contas, o Brasil se apresenta como o agregado político americano que captou o maior número de africanos e que manteve durante mais tempo a escravidão. ${ }^{47}$

Esse ponto de partida se encontra no citado episódio da "Queima de Arquivos" cuja narrativa inclui inúmeras contradições em seu apelo à memória. Trata-se de episódio polêmico em muitas dimensões.

Em primeiro lugar, porque a narrativa afirma uma finalidade que teria sido cumprida: garantir, com a queima das matrículas dos escravos, a não indenização dos senhores de escravos. Efetivamente, o que ocorreu o contrário, pois os senhores de escravos no Brasil, com sua adesão a uma política de adiamento do fim da escravidão: a) implementaram uma política de reorganização da definição de propriedade, com a Lei de Terras $(1850)^{48}$ que impedia que novas forças sociais fossem capazes de

$47 \quad$ ALENCASTRO, Luiz Felipe de. Parecer sobre a Arguição de Descumprimento de Preceito Fundamental, ADPF/186, apresentada ao Supremo Tribunal Federal. In: AUDIÊNCIA Pública sobre a Constitucionalidade de Políticas de Ação Afirmativa de Acesso ao Ensino Superior: Ação de Descumprimento de Preceito Fundamental 186 e Recurso Extraordinário 597.285/RS. Disponível em: <http://www. stf.jus.br/portal/cms/verTexto.asp?servico $=$ processoAudienciaPublicaAcaoAfirmativa>. Acesso em: 20 out. 2015.

48 BERTÚLIO, Dora Lúcia de Lima. Direito e relações raciais: uma introdução crítica ao racismo. 1989. 249 f. Dissertação (Mestrado) - Universidade Federal de Santa Catarina, Florianópolis, 1989; VIEIRA JR., Ronaldo Jorge Araújo. Responsabilização objetiva do Estado. Curitiba: Juruá, 2005. 
enfrentar, no mercado ${ }^{49}$, sua incompetência produtiva, o que lhes garantiu o mascaramento de propriedades subutilizadas como supostamente modernas e produtivas. Logo, houve a indenização aos senhores pela ingerência do Estado na perpetuação hereditária da propriedade que já tinha origem estatal, pois resultava das doações feitas pelo Estado colonial e nacional. Essa prática de "doar" terras públicas, indígenas e quilombolas, se manteve até a Constituição de 1988, apesar das proibições existentes na lei referida, e no período pós 1988, passou a integrar a estratégia de politização administrativa de regularização das terras dessas comunidades. Há, portanto, práticas indenizatórias extensas e contemporâneas de indenizações às famílias de senhores de escravos que se institucionalizaram como privilégios políticos no gerenciamento e expropriação da propriedade privada; b) de igual modo, os senhores de escravos implementaram política fiscal e tributária de subsídios para a garantia da lucratividade de suas propriedades. Isso já estava evidenciado no financiamento da imigração a partir de impostos, ou seja, o Estado foi utilizado para manter excedente de mão de obra capaz de rebaixar o valor da mão de obra geral o que, combinada com a desvalorização racista da mão de obra negra feita pela proliferação institucional do preconceito racial ${ }^{50}$, permitia compensar a incapacidade gerencial da propriedade privada por parte dos senhores. Essa política fiscal inaugura longa tradição de subsídios, favores, isenções, créditos, parcelamentos etc., e de uma retórica "senhorial" de abandono por parte do governo central que, na prática, permitiu a inversão de uma parte da riqueza pública para um setor da economia privada; c) além disso, conseguiram, com essa política de adiamento do fim da escravidão, impor política de escravização ilegal de homens livres que representavam, ao final, a maior parte dos escravos conhecidos. De fato, o adiamento do fim da escravidão baseou-se na importação ilegal de homens e mulheres livres. Logo, os senhores de escravos foram indenizados pela exploração de mão de obra livre escravizada ilegalmente. Ou seja, receberam o lucro de "uma propriedade" que, efetivamente, não lhes pertencia. Essas práticas de expropriação da mão de obra (mais in-

49 FAORO, Raymundo. Existe um pensamento político brasileiro? São Paulo: Ática, 1994.

50 SEYFERTH, Giralda. Construindo a nação: hierarquias raciais e o papel do racismo na política de imigração e colonização. In: MAIO, Marcos Chor; SANTOS, Marcos Ventura (Org.). Raça, ciência e sociedade. Rio de Janeiro: Fiocruz, 1996. tensas que a exploração capitalista e mais perversa ideologicamente do que a escravidão) passaram a compor o marco jurídico de não atribuição de direitos trabalhistas para os trabalhadores rurais e domésticos, ou até mesmo, de tratamento diferenciado, que sobreviveu inclusive na Constituição de 1988.

Enfim, essas três práticas compõem uma longa tradição jurídica e de política pública que avança pela República, compensando, de modo absurdo e contrário ao desenvolvimento das forças produtivas nacionais, as famílias dos senhores de escravos. Assim, o mecanismo de expropriação e constituição da propriedade privada (Pacto Agrário), a política fiscal e tributária favorável aos senhores de escravos (Pacto Fiscal/Tributário), a exclusão de amplos setores dos direitos trabalhistas e, muitas vezes, a mera tolerância de novas formas de escravidão (Pacto Trabalhista) compuseram consolidado arranjo político-institucional que sobrevive até os dias atuais, mas que somente adquire sentido quando compreendido com base na ideia de indenização desses senhores e seus herdeiros. Efetivamente, o monopólio político do mercado pelo Estado reproduz-se em nível local com o estabelecimento, por exemplo, de regras administrativas de comercialização de produtos favoráveis a uma parte dos produtores rurais, ou a nível nacional, com a política migratória subvencionada, a garantia da perpetuação da racialização da propriedade privada no país. Os resultados mais evidentes dessas estratégias foram: a) Há identificação simbólica dos brancos como legítimos proprietários e produtores do desenvolvimento, mesmo quando exploram latifúndios com técnicas de produção rudimentares, com danos ambientais, sem direitos trabalhistas, sendo beneficiados por políticas específicas de crédito e vantagens tributárias; b) Há uma identificação das terras dos pequenos proprietários (sobretudo quando percebidos de modo racializado como "não brancos"), das comunidades tradicionais, dos indígenas e dos quilombolas com o atraso e a impossibilidade prática de que esses grupos possam figurar como sujeitos proprietários.

Em segundo lugar, a ideia de queima de arquivos, ao afirmar a finalidade de "impedir a indenização", oculta dimensão decisiva do modo como o direito reproduz práticas racistas no Brasil. O debate sobre as indenizações necessita ser inserido na política de escravização e supremacia racial do século XIX. Neste contexto, a expressão "para inglês ver" origina-se do modo como o Estado e o Poder Judiciário reagiram à proibição ao tráfico negreiro. 
A proibição foi instituída por diversos dispositivos (Tratado anglo-português de 1818, tratado anglo-brasileiro de 1826, Lei de 7 de novembro de 1831), todavia, não cessou a entrada de africanos ilegalmente escravizados e os senhores de escravos não foram condenados pelo crime de redução à condição de escravo, conforme previa o art. 179 do "Código Criminal" de 1830. Ao final, A Lei de 4 de setembro de 1850, a lei Eusébio de Queirós, determinou outra vez o fim do tráfico negreiro:

porém, na década de 1850, o governo imperial anistiou, na prática, os senhores culpados do crime de sequestro, mas deixou livre curso ao crime correlato, a escravização de pessoas livres. De golpe, os 760.000 africanos desembarcados até 1856 -, e a totalidade de seus descendentes -, continuaram sendo mantidos ilegalmente na escravidão até 1888. Para que não estourassem rebeliões de escravos e de gente ilegalmente escravizada, para que a ilegalidade da posse de cada senhor, de cada sequestrador, não se transformasse em insegurança coletiva dos proprietários, de seus sócios e credores -, abalando todo o país -, era preciso que vigorasse um conluio geral, um pacto implícito em favor da violação da lei. Um pacto fundado nos "interesses coletivos da sociedade", como sentenciou, em 1854, o ministro da Justiça, Nabuco de Araújo, pai de Joaquim Nabuco ${ }^{51}$.

Logo, a lei pública, estabelecida no Parlamento, e as declarações internacionais feitas pelo Estado Brasileiro não aparecem instituindo o Direito na realidade, cuja dinâmica de eficácia normativa sempre foi mais complexa ${ }^{52}$. A promulgação de leis e de acordos internacionais não pode ser identificada nem com o começo ou o fim da escravidão. Vale dizer, a instituição da propriedade privada sobre outros humanos decorre de uma dimensão jurídica prática que incluía a apropriação racial, por parte dos brancos, dos aparatos ideológicos de Estado e dos mecanismos de administração da justiça. De modo direto, a ideia de que a queima iria evitar uma demanda por indenização parece supor que a escravidão no Brasil deixou de existir como fenômeno social de relevância no dia da promulgação da Lei Áurea. Ao invés disso, a permanência

51 ALENCASTRO, Luiz Felipe de. Parecer sobre a Arguição de Descumprimento de Preceito Fundamental, ADPF/186, apresentada ao Supremo Tribunal Federal. In: AUDIÊNCIA Pública sobre a Constitucionalidade de Políticas de Ação Afirmativa de Acesso ao Ensino Superior: Ação de Descumprimento de Preceito Fundamental 186 e Recurso Extraordinário 597.285/RS. Disponível em: <http://www. stf.jus.br/portal/cms/verTexto.asp? servico=processoAudienciaPublicaAcaoAfirmativa $>$. Acesso em: 20 out. 2015.

52 ERLICH, Eugen. Fundamentos da sociologia do direito. Brasília: UnB, 1986. de formas de trabalho escravo no presente e a existência desse pacto de ilegalidade sugerem que a escravidão adentrou o período republicano e se manteve viva em muitas partes do país. As tratativas parlamentares sobre o trabalho doméstico e a leniência institucional quanto às práticas tradicionais dos patrões, especialmente no caso do uso de mão de obra juvenil, bem como a permanência do poder dos coronéis, demonstram como os senhores não precisavam ser indenizados porque ocorreu transformação do status de escravo, mas não necessariamente sua extinção. Há bons argumentos para se suspeitar que a Lei Áurea foi, de certo modo, mais uma "lei pra inglês ver".

Assim, a ideia de queima dos arquivos da escravidão oculta que a matrícula dos escravos serviu como modo de legitimar a propriedade privada ilegal dos es$\operatorname{cravos}^{53} \mathrm{e}$, sobretudo, para frear as demandas por emancipação e os ataques abolicionistas. A escravidão no Brasil foi um fato jurídico que se legitimava com a presunção racista de que ser negro é ser escravo. Desde o início da escravidão colonial, o Estado e a sociedade pouco ou nenhum valor deram à ideia do "justo título" como prova do status de escravo. O justo título de propriedade nunca foi a matrícula, mas a posse branca de um corpo negro. Por essa razão, as análises sobre a existência de um arcabouço jurídico formal de segregação tendem a repetir suas premissas de afastamento da realidade.

A separação analítica feita pela literatura brasileira entre as demandas pelo reconhecimento da liberdade por parte de escravos ilegais versus demandas por reconhecimento da condição de sujeito de direitos dos anônimos brasileiros após a proclamação da República constitui separação ideológica. Essa separação, que produz descontinuidade das lutas sociais, está vinculada a um modelo de história que pretende fazer coincidir as transformações formais do Estado com uma superação efetiva das práticas sociais. Porém, ela está distante da compreensão

53 Neste contexto, como afirma Mamigoniam: "a matrícula dos escravos determinada pela lei do Ventre Livre (28/09/1871) teve a intenção de legalizar a propriedade sobre os africanos trazidos por contrabando, que pela lei de 7/11/1831 deveriam ser considerados livres. Apesar da propriedade sobre os africanos importados desde 1831 ser aceita em transações comerciais e ser garantida pelo governo, o receio demonstrado pelos senhores de escravos em petições e as justificativas apresentadas no debate do projeto da lei de 1871 indicam que ela era considerada instável." MAMIGONIAM, Beatriz Gallotti. O Estado nacional e a instabilidade da propriedade escrava: a Lei de 1831 e a matrícula dos escravos de 1872. Almanack, Guarulhos, n. 2, p. 20-37, 2o semestre de 2011. 
empírica das realidades brasileiras. A cisão na história produzida, supostamente, pela mudança do marco legal (Monarquia/República) pretende nos convencer de que há uma ruptura na relação entre as elites e os grupos sociais subalternos e/ou entre estes grupos subalternos. Tal cisão é um dos mecanismos ideológicos pelos quais se pretende construir, simbolicamente, a ideia de povo como totalidade amorfa ou como símbolo de pluralidade integrada de raças. Entretanto, as lutas dos negros em torno do reconhecimento de sua humanidade (Dignidade Humana) e em oposição aos mecanismos institucionais de racialização não desaparecem com o fim da abolição formal, mas passam a ser fortemente "apagadas" pela tradição negreira.

Em terceiro lugar, a ideia de queima de arquivos, ao afirmar a finalidade de "impedir a indenização", apaga a disputa política existente em torno das matrículas e das indenizações. $\mathrm{O}$ argumento da ilegalidade da escravidão e a dívida para com os escravos esteve na consciência política de parte do movimento abolicionista. O moderado Joaquim Nabuco foi consciente de que a "escravidão era um Crime contra a Humanidade", muito antes que o termo fosse utilizado para descrever os horrores da Segunda Guerra $^{54}$. A propósito José do Patrocínio afirmava:

o problema da escravidão está neste pé. A lei de 1831 suprimiu o tráfico e não só declarou criminosos os introdutores, como obrigados à restituição do africano os compradores. Há quarenta e nove anos e dois dias, pois, nenhum africano podia mais ser escravizado no Brasil.

A especulação da carne humana, porém, havia entrado nos hábitos nacionais, e durante vinte e três anos continuou o crime do tráfico. [...]

E, pois, quase matematicamente certo que há reduzido a escravidão um número de 700.000 homens, metade, portanto, da escravatura atual.

Ora, é de lei que o salário do homem escravizado seja pago por quem o escravizou, ou quem herdou os capitais deste.

Logo, os atuais proprietários de escravos devem à sociedade em geral, ou melhor, à raça negra, quarenta e nove anos de salário. Fazendo o cálculo a 200 rs. por dia, e não computando já o espaço que vai de 1831 a 1854 , tempo que, por deferência com os srs. fazendeiros deixamos de incluir no cálculo, temos:

Por um dia de trabalho

de 700.000 homens escravizados..... 140:000\$000

54 NABUCO, Joaquim. A escravidão. Recife: Fundação Joaquim Nabuco, 1988.
Por um ano. $. .51 .100: 000 \$ 000$

Em 26 anos 1.328.600:000\$000

Apesar do número avultado que dá o cálculo, é preciso notar a insignificância do salário que foi marcado. Nunca no Brasil um trabalhador de enxada ganhou, no período apontado, semelhante ridicularia. [...]

A conclusão a tirar é, pois, que sendo o número atual dos escravos mais ou menos 1.435.000, dos quais 700.000 emancipados por força da lei de 1831 e subsequentes leis de 1850 e 1854, segue-se que há em salários da raça negra 1.328.600.000\$ para indenizar a emancipação dos 735.000 restantes." ${ }^{55}$.

Enfim, o cálculo de José do Patrocínio demonstra que há história vencida no processo abolicionista, capaz de redefinir a querela sobre a queima dos arquivos. A indenização não era uma reivindicação apenas dos supostos proprietários (de uma propriedade que, de fato, era ilegítima e ilegal), mas também daqueles que eram concebidos como propriedade, excluídos da condição de humanidade e da cidadania. Mais ainda, os "patriarcas" da abolição e da fundação da República, dada a publicidade da tese defendida por José do Patrocínio, tinham a possibilidade de compreender essa demanda. Não o fizeram. O destino dos negros na abolição e a continuidade da clivagem social por raça/cor não foi efeito das forças impessoais do mercado, mas de um conjunto de decisões políticas e, como se pode constatar, tais decisões encontraram um largo campo de ação distante da jurisdicionalização das demandas. A afirmação de que apenas se intentava apagar os rastros deixados para indenização dos senhores oculta a disputa política e a estratégia de favorecimento dos senhores. Apaga-se especialmente o conflito social que a exploração ilegal do trabalho provocava e, obviamente, a responsabilidade dos Republicanos que fizerem previamente a opção por não indenizarem os escravos ilegais pelo seu trabalho.

Em quarto lugar, a ideia de queima dos arquivos da escravidão tende a indicar a impossibilidade prática de se fazer história da escravidão devido à eliminação das fontes. Não obstante, como se tem destacado e como comprovou a produção historiográfica sobre a escravidão

55 PATROCÍNIO, José. Discurso na Gazeta de Notícias de 06 setembro de 1880 . In: (Org.). A Campanha Abolicionista. [s.l]: Ministério da Cultura, Fundação Biblioteca Nacional, [s.d.]. Disponível em: <http://www.dominiopublico.gov.br/download/texto/bn000110.pdf $>$. Acesso em: 20 out. 2015. 
posterior a década de $1980^{56}$, havia e há inúmeras fontes documentais da escravidão $0^{57}$. Logo, aquela ideia teve como efeito servir de barreira para o desenvolvimento da pesquisa no país. Pior ainda, os arquivos que contêm documentação têm sido destruídos silenciosamente pelo descaso público ${ }^{58}$ e pela ausência de uma interpretação adequada do conteúdo da tutela constitucional.

Por sua vez, é preciso pensar um pouco mais na palavra "arquivo". Essa palavra remete a uma forma de organizar elementos, ou melhor, de constituir "algo" como elementos a partir de uma organização. $\mathrm{O}$ arquivo portanto, não apenas recolhe e reconhece um dado elemento existente "na" história. $\mathrm{O}$ arquivo materializa e confere operacionalidade a uma verdade ${ }^{59}$. Ou seja, o arquivo constitui-se com base em uma dada concepção histórica sobre a História. Mesmo as coleções privadas expressam gostos pessoais, indicam valores no mercado de objetos, legitimam posições sociais e ordenam-se com base em mapas de reconhecimento social. O episódio da queima das matrículas remete a um tipo de valorização do meio de prova: o documento com fé pública (peça móvel, escrita, reconhecida por um funcionário etc.). Logo, não haveria nenhuma verdade mais verdadeira do que aquela que a burocracia legitima (muito embora se saiba que as declarações de propriedade eram falsas). Paradoxalmente, apesar do apelo ao documento, a história oficial desde o Império esteve calcada no uso dos "relatos" (dos letrados, membros da burocracia, padres, viajantes) que, por sua condição, passavam a ser reconhecidos como fontes dos fatos. De modo paralelo, a retórica documental do passado, ao que parece, constitui mais uma retórica dos alforriados e reescravizados do que dos senhores de escravos. De fato, um negro, em nosso sistema legal, foi presumidamente um escravo, devendo provar sua liberdade.

56 WOLKMER, Antônio Carlos. Paradigmas, historiografia, crítica e direito moderno. Revista da Faculdade de Direito, Curitiba, v. 28, n. 28, p. 55-67, 1994-1995.

57 CHALHOUB, Sidney. Visões da liberdade: uma história das últimas décadas da escravidão na corte. São Paulo: Companhia das Letras, 1990.

58 SLENES, Robert. Escravos, cartórios e desburocratização: o que Rui Barbosa não queimou será destruído agora? Revista Brasileira de História, São Paulo, v. 5, n. 10, p. 166-197, mar./ago. 1985.

59 "Historiadores não sobrevivem sem arquivos" e do mesmo modo, "invertendo o postulado inicial: arquivos não sobrevivem sem historiadores." AGUIAR, Marcos Magalhães de. Historiadores e arquivos: testemunho de uma experiência. Revista Múltipla, Brasília, v. 5, n. 7, p. 109-116, dez. 1999.
O documento prova a exceção ontológica, ou seja, a liberdade de um "negro" (que era presumidamente reconhecido como naturalmente escravo). Isso poderia remeter a um primeiro conjunto de problemas: para que negros, no período pós-escravista, julgaram necessário valorizar um episódio como a queima documental que provava a sua condição de escravos? Haveria continuidade de demandas trabalhistas contra seus senhores? Quereriam provar algo? Não haveria demanda pelo registro das origens, ou melhor, dos dados de seu nascimento? Não haveria a suposição de que a matrícula era o caminho para a regularização do registro civil de nascimento de inúmeros negros (in)documentados e sem sobrenome? Não estariam agora submetidos à condição de não existentes? Não seria a falta de documentos, com a ação repressiva das polícias urbanas utilizada, como ainda hoje, para colocar essa população na condição de não cidadãos? O apagamento dos arquivos não teria sido mais uma estratégia de desconstrução da cidadania dos negros?

Nesse contexto, pode-se sugerir segundo conjunto de questões sobre a retórica das fontes documentais para refazer a história da escravidão, o papel conferido aos relatos dos ex-escravos. Um pouco de prática jurídica indicaria que, mesmo no caso dos inquéritos e processos judiciais, quando aparecem algumas falas atribuídas a esses sujeitos é nítida a presença de um filtro racial que marca as fontes documentais em geral. Os relatos dos próprios negros ex-escravos são uma raridade. Isso se insere na própria lógica do racismo, que não se estrutura apenas pelo ódio ou desprezo, mas, sobretudo, pela indiferença pelo ponto de vista das vítimas. A ideia da queima de arquivos oculta que a maior barreira contra a garantia da memória sobre a escravidão foi o desprezo em relação a palavra dos negros que estavam vivos naquele momento. De fato, não se encontra, efetivamente, nas fontes documentais construídas por um poder institucional racializado, uma percepção da escravidão em seu conjunto, pois o negro foi excluído como sujeito do conhecimento e, quando muito, foi transformado em objeto de estudo pela Antropologia nascente ${ }^{60}$.

De fato, a indiferença e a estratégia de silenciar compuseram esse quadro, como argumenta José Jorge de Carvalho:

temos que definir o racismo não pela adesão a um credo de superioridade racial, mas pelo

60 DUARTE, Evandro C. Piza. Criminologia e racismo: introdução à criminologia brasileira. Curitiba: Juruá, 2002. 
efeito continuado dos discursos que celebram a mestiçagem e silenciaram a afirmação da condição de negro no Brasil. Nesse sentido, quando Gilberto Freyre defendeu a morenidade e repudiou a presença no Brasil de ideologias de negritude, ele, branco, utilizou-se de sua grande influência para impedir que os negros afirmassem sua identidade de negros. E por que o fez? Porque o discurso da negritude deslocaria a discussão de uma celebração abstrata da interpretação das culturas para uma denúncia veemente das condições de vida precárias e sempre desiguais, enfrentadas pela população negra no país da suposta democracia racial ${ }^{61}$.

Enfim, a retórica da ideia de queima de arquivos também se insere numa certa gestão do conhecimento sobre o passado em que as "vozes negras" são sempre consideradas inadequadas para a descrição das "vidas negras", cabendo aos filhos da elite a elaboração de uma narrativa oficial da escravidão. Essa voz autorizada repete-se e constituiu-se no monopólio acadêmico em áreas como a Antropologia, a História e a Sociologia ao tratar da gestão das linhas de pesquisa. Essa mesma voz constitui os documentos cotidianos e os relatos dos viajantes. A queima dos arquivos da escravidão (se com isso se pretende indicar a impossibilidade de uma historia da escravidão que leve em conta as demandas sociais dos negros) tornou-se processo que se organizou e se institucionalizou como presente ao longo do século XX.

Essa última sugestão remete à quinta ideia sobre a queima dos arquivos da escravidão. De fato, ela poderia ser lida com base na noção de "trauma histórico", ou seja, como uma construção social sobre o passado que constrói versão distinta de fatos efetivamente ocorridos, mas que tenta elaborar, simbolicamente, experiência real e traumática para determinado grupo social. Nesse caso, não interessa se Ruy Barbosa efetivamente ordenou a queima ou se ela estava ordenada antes de sua chegada, muito menos se a queima foi "verdadeira ou não", ou seja, não interessam se todas as "fontes" foram objetivamente perdidas. Ao invés disso, interessa o que a ideia de "queima dos arquivos" significa como retórica no argumento das vítimas desse processo de negação: a impossibilidade de contato

\footnotetext{
CARVALHO, José Jorge de. Ações afirmativas para negros na pós-graduação, nas bolsas de pesquisa e nos concursos para professores universitários como resposta ao racismo acadêmico endêmico. In: SILVA, Petronilha B. G.; SILVÉRIO, Valter Roberto (Org.). Educação e ações afirmativas: entre a injustiça simbólica e a injustiça econômica. Brasília: INEP, 2003. p. 161-192. p. 175.
}

institucional com o passado. E, nesse caso, torna-se necessário destacar que essa impossibilidade não foi construída apenas pela falta de liberdade de expressão, mas, sobretudo, pela produção massiva de discursos ou pelo monopólio ${ }^{62}$ desses discursos sobre o passado. Esse monopólio, assim como a exclusão e a repressão dos negros na esfera pública, parecem estar na origem da necessidade de buscar mito de perda ou de impossibilidade da memória que, apesar de ser considerado mito, carrega elemento de contato com a realidade, constituindo-se em forma de expressar a condição de vítima de apagamento na História.

A crítica de nossa tradição negreira e a consideração da queima de arquivos da escravidão como expressão subjetiva de processo institucional de apagamento são os dois pontos de partida para leitura constitucional do tema da memória em relação aos negros.

\section{Um lembrete: os arquivos apagados da me- mória do presente}

A Constituição de 1988 é uma Constituição memoriosa. Está preocupada em lembrar e permite revisão do passado. Depois de cem anos da abolição formal, a Constituição de 1988 é a primeira a reconhecer em nossa história a presença da escravidão e do colonialismo, usando palavras como racismo, afro-brasileiros, indígenas e quilombos. De fato, em alguns dispositivos é possível perceber que a escravidão surge como um problema que atravessa a história e vem provocar efeitos no presente. O artigo 215 afirma que o "Estado garantirá a todos o pleno exercício dos direitos culturais e acesso às fontes da cultura nacional", reconhecendo a existência de "manifestações das culturas populares, indígenas e afro-brasileiras", de "grupos participantes do processo civilizatório nacional", de "diferentes segmentos étnicos nacionais". Já $\mathrm{o}$ artigo 216 dispõe que

"constituem patrimônio cultural brasileiro os
bens de natureza material e imaterial, tomados
individualmente ou em conjunto, portadores de
referência à identidade, à ação, à memória dos
diferentes grupos formadores da sociedade bra-
sileira", determinando em seu parágrafo quinto
que "ficam tombados todos os documentos e os
sítios detentores de reminiscências históricas
dos antigos quilombos".

$\mathrm{Na}$ ordem constitucional da cultura e no título

62 FOUCAULT, Michel. A ordem do discurso. São Paulo: Loyola, 1996. 
dedicado aos indígenas, bem como em artigos esparsos que lhes fazem referência, a pluralidade das formas de vida e de culturas alcançou maior densidade constitucional, revelando a tensão entre o pluralismo como expressão identitária de grupos sociais e o pluralismo social como valor reconhecido pela sociedade brasileira em sua "unidade". No artigo 215, o Estado, para garantir a todos o pleno exercício dos direitos culturais e acesso às fontes da cultura nacional, necessita proteger manifestações culturais de grupos específicos, enunciados com base no reconhecimento histórico de sua exclusão (populares, indígenas e afro-brasileiras). Ao mesmo tempo, o dispositivo permite identificar outros grupos a partir de um modelo de interação definido como processo (processo civilizatório nacional). O Estado estabelece marcos simbólicos para diferentes segmentos étnicos nacionais, valoriza a identidade étnico regional, mas também propugna pela defesa e valorização de um patrimônio cultural "brasileiro". Observe-se que o patrimônio brasileiro não é definido com a busca de uma identidade homogênea da brasilidade, ao contrário, na definição do art. 216, a "brasilidade" encontra-se na diversidade e, especificamente, depende da consideração de que determinados grupos necessitam ser "nominados", ou seja, empoderados simbólica e materialmente nas políticas estatais.

A superação da perspectiva homogeneizante e de "integração" apagadora das diferenças marca a característica multicultural (ou intercultural), própria do novo paradigma do Estado Democrático de Direito, também verificada na Convenção 169, da Organização Mundial do Trabalho (OIT) em 1989, sobre Povos indígenas e tribais ${ }^{63}$.

A ordem constitucional da cultura foi assim capaz de integrar conceitualmente a complexidade e a especificidade das diferenças como elemento fundamental do princípio da igualdade. Enfim, o pluralismo como princípio na Constituição não se situa fora de uma referência ao contexto plural onde ela foi elaborada, indica uma concepção pluralista que, ao ser seletiva, reconstrói memória constitucional da igualdade e da liberdade negadas ${ }^{64}$, estabelecendo um âmbito

63 SCOTTI, Guilherme. Direitos humanos e multiculturalismo: o debate sobre o infanticídio indígena no Brasil. Revista Jurídica da Presidência, Brasília, v. 15, n. 106, p. 489-515, jun./set. 2013.

64 HALL, Stuart. Da diáspora, identidades e mediações culturais. Belo Horizonte: UFMG, 2006; BUCK-MORSS, Susan. mínimo de normatividade capaz de acoplar o texto às demandas políticas que não eram satisfeitas no âmbito dos mecanismos conhecidos das descrições de funcionamento da política, tais como os partidos políticos ou os sindicatos, e abrindo espaço para uma política de reconhecimento.

Infelizmente, o pensamento jurídico nacional dominante já se apressou, no presente, em "queimar os arquivos da escravidão", deixando de conferir eficácia interpretativa às inovações trazidas pela Constituição. Insistem, os juristas de sempre, de ontem e de hoje, em ler o direito de propriedade, a liberdade religiosa, o acesso à justiça, a politica cultural e educacional etc., de forma alheia aos quinhentos anos de história de aprendizado constitucional. Para além da retórica do "Nacional", é necessário retomar as dimensões universais e transformadoras das lutas locais pela construção de direitos.

\section{Referências}

AGAMBEN, Giorgio. Homo Sacer: o poder soberano e a vida nua. Belo Horizonte: UFMG, 2002. v. 1.

AGUIAR, Marcos Magalhães de. Historiadores e arquivos: testemunho de uma experiência. Revista Múltipla, Brasília, v. 5, n. 7, p. 109-116, dez. 1999.

AGUIAR, Thaís. A história como recurso da mimese política brasileira. Sociedade e Cultura, Goiânia, v. 10, n. 2, p. 227-239, 2007. Disponível em: <http://revistas.ufg.br/ index.php/fchf/article/viewArticle/3143>. Acesso em: 20 out. 2015.

ALENCASTRO, Luiz Felipe de. Parecer sobre a Arguição de Descumprimento de Preceito Fundamental, ADPF/186, apresentada ao Supremo Tribunal Federal. In: AUDIÊNCIA Pública sobre a Constitucionalidade de Políticas de Ação Afirmativa de Acesso ao Ensino Superior: Ação de Descumprimento de Preceito Fundamental 186 e Recurso Extraordinário 597.285/RS. Disponível em: <http://www. stf.jus.br/portal/cms/verTexto.asp?servico $=$ processo $A u-$ dienciaPublicaAcaoAfirmativa>. Acesso em: 20 out. 2015.

ALTHUSSER, Louis. Aparelhos ideológicos de estado: nota sobre os aparelhos ideológicos de estado. Rio de Janeiro: Graal, 1985.

ANDRADE, Vera Regina Pereira de. A ilusão de seguran-

Hegel e o Haiti. Critical Inquiry, Chicago, v. 26, n. 4, p. 821865, 2000. p. 821-865. 
ça jurídica: do controle da violência à violência do controle penal. Porto Alegre: Livraria do Advogado, 1997.

ARAÚJO, Ricardo Benzaquen de. Guerra e paz: casa-grande e senzala e a obra de Gilberto Freyre nos anos 30. Rio de Janeiro: 34, 1994.

ARENDT, Hannah. Origens do totalitarismo: antissemitismo, imperialismo, totalitarismo. Trad. Roberto Luis Raposo. São Paulo: Companhia das Letras, 1989.

AUGRAS, Monique. A ordem na desordem: a regulamentação do desfile das escolas de samba e a exigência de "motivos nacionais". Revista Brasileira de Ciências Sociais, São Paulo, v. 8, n. 21, p. 90-103, fev. 1993.

BARATTA, Alessandro. Criminologia crítica e crítica do direito penal: introdução á sociologia do direito penal. Rio de Janeiro: Revan, 1997.

BARROS, José D’Assunção. A construção social da cor: diferença e desigualdade na formação da sociedade brasileira. Petrópolis: Vozes, 2009.

BARROSO, Luís Roberto. O direito constitucional e a efetividade de suas normas: limites e possibilidades da constituição brasileira. São Paulo: Renovar, 2003.

BERTÚLIO, Dora Lúcia de Lima. Direito e relações raciais: uma introdução crítica ao racismo. 1989. 249 f. Dissertação (Mestrado) - Universidade Federal de Santa Catarina, Florianópolis, 1989.

BOSI, Alfredo. Dialética da colonização. São Paulo: Companhia das Letras, 1992.

BOXER, Charles Ralph. Relações raciais no império colonial português 1415-1825. Porto: Afrontamento, 1977.

BRASIL. Supremo Tribunal Federal. Crime de Racismo e Antissemitismo: um julgamento histórico no STF, habeas corpus n. ${ }^{\circ}$ 82.424/RS. Brasília: STF, 2004.

BUCK-MORSS, Susan. Hegel e o Haiti. Critical Inquiry, Chicago, v. 26, n. 4, p. 821-865, 2000.

CARNEIRO, Edson de Souza. Os cultos de origem africana no Brasil. In: Candomblés da Bahia. 3. ed. Rio de Janeiro: Conquista, 1961.

CARNEIRO, Sueli; CURY, Cristiane Abdon. O candomblé. In: CONGRESSO DE CULTURA NEGRA DAS AMÉRICAS, 3., São Paulo, 1982. p. 176-191.

CARVALHO NETTO, Menelick de. A hermenêutica constitucional e os desafios postos aos direitos fundamentais. In: SAMPAIO, José Adércio Leite (Org.). Jurisdição constitucional e os direitos fundamentais. Belo Horizonte: Del Rey, 2003. p. 141-164.
CARVALHO NETTO, Menelick; SCOTTI, Guilherme. Os direitos fundamentais e a (in)certeza do direito: a produtividade das tensões principiológicas e a superação do sistema de regras. Belo Horizonte: Fórum, 2011.

CARVALHO, José Jorge de. Ações afirmativas para negros e índios no ensino superior: as propostas dos NEABs. In: SANTOS, Renato Emerson dos; LOBATO, Fátima (Org.). Ações afirmativas: políticas públicas contra as desigualdades raciais. Rio de Janeiro: DP\&A, 2003. p. 191-203.

CARVALHO, José Jorge de. Ações afirmativas para negros na pós-graduação, nas bolsas de pesquisa e nos concursos para professores universitários como resposta ao racismo acadêmico endêmico. In: SILVA, Petronilha B. G.; SILVÉRIO, Valter Roberto (Org.). Educação e ações afirmativas: entre a injustiça simbólica e a injustiça econômica. Brasília: INEP, 2003. p. 161-192.

CARVALHO, José Jorge de. Exclusão racial na universidade brasileira: um caso de ação negativa. In: Queiroz, Delcele Mascarenhas (Coord.). O negro na universidade. Salvador: Novos Toques, 2002. p. 79-99.

CARVALHO, José Jorge de. Inclusão étnica e racial no Brasil: a questão das cotas no ensino superior. São Paulo: Attar, 2006.

CARVALHO, José Murilo de. A utopia de Oliveira Vianna. Revista Estudos Históricos, Rio de Janeiro, v. 4, n. 7, p. 8189, 1991. Disponível em: <http://virtualbib.fgv.br/ojs/index. php/reh/article/viewArticle/2310>. Acesso em: 20 out. 2015.

CAVALLEIRO, Eliane dos Santos. Discursos e práticas racistas na educação infantil: a produção da submissão social e do fracasso escolar. In: MARTINS, Juarez; LIMA, Maria José Rocha (Org.). Educação, etnias e combate ao racismo: contribuição ao combate. Brasília: PT, 2001.

CHALHOUB, Sidney. Visões da liberdade: uma história das últimas décadas da escravidão na corte. São Paulo: Companhia das Letras, 1990.

CHAUÍ, Marilena de Sousa. Brasil: mito fundador e sociedade autoritária. São Paulo: Fundação Perseu Abramo, 2000.

CHAUÍ, Marilena de Sousa. Conformismo e resistência: aspectos da cultura popular no Brasil. São Paulo: Brasiliense, 1986.

CHIAVENATO, Júlio J. O negro no Brasil: da senzala à Guerra do Paraguai. São Paulo: Brasiliense, 1986.

DUARTE, Evandro C. Piza. Criminologia e racismo: introdução à criminologia brasileira. Curitiba: Juruá, 2002.

DUARTE, Evandro C. Piza. Do medo da diferença à liberdade com igualdade: as ações afirmativas para negros no ensino superior e os procedimentos de identificação de seus beneficiários. 2011. f. Tese (Doutorado) - Curso de Pós-Graduação em Direito, Universidade de Brasília, Brasília, 2011. 
DUARTE, Evandro C. Piza; SCOTTI, Guilherme. História e memória nacional no discurso jurídico: o julgamento da ADPF 186. Universitas Jus, Brasília, v. 24, n. 3, p. 33-45, 2013. doi: 10.5102/unijus.v24i3.2611.

DUSSEL, Enrique D. 1492, o encobrimento do outro: a origem do mito da modernidade. Petrópolis: Vozes, 1993.

DWORKIN, Ronald. O império do direito. São Paulo: M. Fontes, 1999.

ERLICH, Eugen. Fundamentos da sociologia do direito. Brasília: UnB, 1986.

FANON, Frantz. Os condenados da terra. Trad. de José Laurênio de Melo. Rio de Janeiro: Civilização Brasileira, 1979.

FAORO, Raymundo. Existe um pensamento politico brasileiro? São Paulo: Ática, 1994.

FOUCAULT, Michel. A ordem do discurso. São Paulo: Loyola, 1996.

FREYRE, Gilberto. Casa-grande e senzala: formação da família brasileira sob o regime patriarcal. São Paulo: Global, 2004.

FREYRE, Gilberto. Nordeste: aspectos da influência da cana sobre a vida e a paisagem do nordeste do Brasil. Rio de Janeiro: Record, 1989.

FRIGERIO, Alejandro. Capoeira: da arte negra a esporte branco. Revista Brasileira de Ciências Sociais, São Paulo, v. 4, n. 10, p. 85-98, jun. 1989.

GRIMBERG, Keila; BORGES, Magno Fonseca, SALLES, Ricardo. Rebeliões escravas antes da extinção do tráfico. In: ___ (Org.). O Brasil imperial: 1808-1831. Rio de Janeiro: Civilização Brasileira, 2009. v. 1. p. 235-270.

HALL, Stuart. Da diáspora: identidades e mediações culturais. Belo Horizonte: UFMG, 2006.

IANNI, Octávio. A ideia de Brasil moderno. São Paulo: Brasiliense, 1994.

IANNI, Octávio. Escravidão e racismo. São Paulo: Hucitec, 1988.

LAFER, Celso. A internacionalização dos direitos humanos: constituição, racismo e relações internacionais. Barueri: Manole, 2005.

MAMIGONIAM, Beatriz Gallotti. O Estado nacional e a instabilidade da propriedade escrava: a Lei de 1831 e a matrícula dos escravos de 1872. Almanack. Guarulhos, n. 02 , p. 20-37, 2o semestre de 2011.
MATTOS, Wilson Roberto de. Práticas culturais religiosas negras em São Paulo: dos territórios destruídos aos territórios reconquistados. 1994. Dissertação (Mestrado) - Pontifícia Universidade Católica de São Paulo, Barueri, 1994.

MOURA, Clóvis. Dialética radical do negro no Brasil. São Paulo: Anita, 1994.

MOURA, Clóvis. Sociologia do negro brasileiro. São Paulo: Ática, 1988.

MUNANGA, Kabengele. Rediscutindo a mestiçagem no Brasil. Belo Horizonte: Autentica, 2004.

NABUCO, Joaquim. A escravidão. Recife: Fundação Joaquim Nabuco, 1988.

ORTIZ, Renato. Cultura brasileira e identidade nacional. São Paulo: Brasiliense, 1994.

PATROCÍNIO, José. Discurso na Gazeta de Notícias de 06 setembro de 1880. In: (Org.). A Campanha Abolicionista. [s.l]: Ministério da Cultura, Fundação Biblioteca Nacional, [s.d.]. Disponível em: <http://www.dominiopublico.gov.br/ download/texto/bn000110.pdf>. Acesso em: 20 out. 2015.

POTIGUAR, Alex Lobato. Igualdade e liberdade: a luta por reconhecimento da igualdade como direito à diferença no discurso do ódio. 2009. 155 f. Dissertação (Mestrado) - Programa de Pós-Graduação, Faculdade de Direito, Universidade de Brasília, 2009.

RIBEIRO, Darcy. Sobre o Óbvio. In: SIMPÓSIO SOBRE ENSINO PÚBLICO; REUNIÃO DA SOCIEDADE BRASILEIRA PARA O PROGRESSO DA CIÊNCIA, 29., São Paulo. [documentos...]: São Paulo. [s.n], 1977. Mimeo.

RIBEIRO, Darcy. Uma introdução à casa grande e senzala. In: Gentidades. Porto Alegre: L\&PM, 2001. p. 9-68.

RIGG, Bryan Mark. Os soldados judeus de Hitler: a história que não foi contada das leis raciais nazistas e de homens de ascendência judia nas forças armadas alemãs. Trad. Marcos Santarrita. Rio de Janeiro: Imago, 2003.

RODRIGUES, Ana Maria. Samba negro, espoliação branca. São Paulo: Hucitec, 1984.

ROSSI, Paolo. O passado, a memória e o esquecimento. São Paulo: Unesp, 2010.

SCOTTI, Guilherme. Direitos humanos e multiculturalismo: o debate sobre o infanticídio indígena no Brasil. Revista Jurídica da Presidência, Brasília, v. 15, n. 106, p. 489-515, jun./set. 2013. 
SEYFERTH, Giralda. Construindo a nação: hierarquias raciais e o papel do racismo na política de imigração e colonização. In: MAIO, Marcos Chor; SANTOS, Marcos Ventura (Org.). Raça, ciência e sociedade. Rio de Janeiro: Fiocruz, 1996.

SILVA JÚNIOR, Paulo Melgaço. Mercedes Baptista: a criação da identidade negra na dança. 2007. Disponível em: $\quad<$ http://ambiente.educacao.ba.gov.br/conteudos/ download/167.pdf>. Acesso em: 20 out. 2015.

SILVA, Jorge da. Direitos civis e relações raciais no Brasil. Rio de Janeiro: Luam, 1994.

SILVA, José Afonso da. Ordenação constitucional da cultura. São Paulo: Malheiros, 2001.

SILVA, P. V. B. Racismo em livros didáticos. Belo Horizonte: Autêntica, 2008.

SILVA, Petronilha Beatriz Gonçalves e. Diversidade étnico-cultural e currículos escolares: dilemas e possibilidades. Cadernos Cedes, Campinas, n. 32, p. 25-84, 1993.

SKIDMORE, Thomas. Preto no branco. Rio de Janeiro: Paz e Terra, 1976.

SLENES, Robert. Escravos, cartórios e desburocratização: o que Rui Barbosa não queimou será destruído agora? In: Revista Brasileira de História, São Paulo, v. 5, n. 10, p.166197, mar./ago. 1985.

SOARES, Carlos Eugênio Líbano. A capoeira escrava e outras tradições rebeldes no Rio de Janeiro (1808-1850). Campinas: Unicamp, 2002.
TABORDA, Radagasio. Crestomatia cívica: uma só pátria, uma só bandeira! Porto Alegre: Livraria do Globo, 1938.

THOMPSON, Augusto. Quem são os criminosos? Rio de Janeiro: Achiamé, 1983.

VAINFAS, Ronaldo. Ideologia e escravidão: os letrados e a sociedade escravista no Brasil colonial. Petrópolis: Vozes, 1986.

VIANNA, Francisco José de Oliveira. Evolução do povo brasileiro. Rio de Janeiro: J. Olympio, 1956.

VIANNA, Francisco José de Oliveira. Instituições políticas brasileiras. Belo Horizonte: Atalaia, 1987. v. 1.

VIANNA, Francisco José de Oliveira. Instituições políticas brasileiras. Belo Horizonte: Atalaia, 1987. v. 2.

VIEIRA JR., Ronaldo Jorge Araújo. Responsabilização objetiva do Estado. Curitiba: Juruá, 2005.

VON MARTIUS, Carlos Frederico. Como se deve escrever a historia do Brasil. Jornal do Instituto Histórico e Geográfico Brasileiro, Rio de Janeiro, n. 24, p. 401-402, jan. 1845.

WOLKMER, Antônio Carlos. Paradigmas, historiografia, crítica e direito moderno. Revista da Faculdade de Direito, Curitiba, v. 28, n. 28, p. 55-67, 1994-1995.

ZEA, Leopoldo. Discurso desde a marginalização e a barbárie; seguido de, A filosofia latino-americana como filosofia pura e simplesmente. Rio de Janeiro: Garamond, 2005. 